\title{
Northern Quahog (Hard Clam) Mercenaria Mercenaria Abundance And Habitat Use In Chesapeake Bay
}

Roger L. Mann

Virginia Institute of Marine Science

JM Harding

Melissa Southworth

Virginia Institute of Marine Science

JA Wesson

Follow this and additional works at: https://scholarworks.wm.edu/vimsarticles

Part of the Marine Biology Commons

\section{Recommended Citation}

Mann, Roger L.; Harding, JM; Southworth, Melissa; and Wesson, JA, "Northern Quahog (Hard Clam) Mercenaria Mercenaria Abundance And Habitat Use In Chesapeake Bay" (2005). VIMS Articles. 456. https://scholarworks.wm.edu/vimsarticles/456 


\title{
NORTHERN QUAHOG (HARD CLAM) MERCENARIA MERCENARIA ABUNDANCE AND HABITAT USE IN CHESAPEAKE BAY
}

\author{
ROGER MANN, ${ }^{1 *}$ JULIANA M. HARDING, ${ }^{1}$ MELISSA J. SOUTHWORTH ${ }^{1}$ AND \\ JAMES A. WESSON ${ }^{2}$ \\ ${ }^{1}$ Department of Fisheries Science, Virginia Institute of Marine Science, Gloucester Point, Virginia \\ 23062; ${ }^{2}$ Shellfish Conservation and Repletion Division, Virginia Marine Resources Commission, P.O. \\ Box 756, Newport News, Virginia 23607
}

\begin{abstract}
Recent (2001-2002) surveys of hard clam Mercenaria mercenaria density and distribution, using patent tongs in a stratified random design ( $n=7,358$ stations) in lower Chesapeake Bay are not consistent with historic descriptions of clam habitats

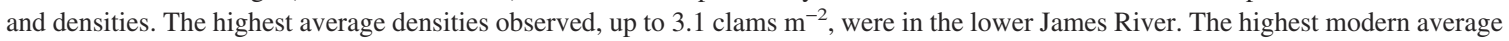
density observed is half that of clam densities commonly observed in these same habitats during the early 1970s. Current distribution is significantly affected by water depth and substrate composition. Hard clam density in Chesapeake Bay is positively associated with increasing sediment grain size; $78 \%$ of all clams collected were found in shell or sand habitats. However, $44 \%$ of sand habitats and $54 \%$ of shell habitats were unoccupied suggesting that even habitat types that typically support higher clam densities may currently be underused.
\end{abstract}

KEY WORDS: hard clam, Mercenaria mercenaria, habitat, substrate, Chesapeake Bay

\section{INTRODUCTION}

The northern quahog (hard clam) Mercenaria mercenaria has an ancient lineage originating in the North Pacific, migrating along the eastern Pacific rim and crossing into the Atlantic basin prior to the emergence of the Panama isthmus (Harte 2001). The subsequent northern range extension and isolation in the western North Atlantic has resulted in a current latitudinal range extending from the Canadian provinces to the Florida Keys (Harte 2001). The enormity of this range speaks to the tolerance of the species to a wide range of temperatures and salinities (Grizzle et al. 2001). Over this latitudinal range, $M$. mercenaria occupies coastal tidal habitats from soft sediments within seagrass beds to sand and shell substrates on or near oyster beds (Carriker 1959, Wells 1957, Saila et al. 1967, Fegley 2001, Peterson 2001).

The Chesapeake Bay is located midway in this latitudinal range, and hard clam populations occur at salinities $>12$ ppt (Haven et al. 1973, Roegner \& Mann 1991). The distribution data from Roegner and Mann (1991) suggest a broad niche for the species in Chesapeake Bay. Hard clams are dominant, long lived members of the infaunal community that facilitate benthic pelagic coupling through suspension feeding within this zone. They are notably lacking in major diseases. Their combined longevity and habit of recording their entire life history in their shell structure make them attractive long-term monitors of the local environment. Although the ecological contributions of hard clam populations to energy transfer, elemental cycling and amelioration of eutrophication are known (Grizzle et al. 2001), the bathymetric and substrate preferences of the species in these habitats remain poorly defined. The absence of such data presents challenges in terms of estimating the spatial ecologic contributions of local benthic communities as well as evaluation of long-term population trends in the face of anthropogenic impacts.

As an attractive commercial species, the hard clam supports a valuable fishery in the Virginia portion of the Chesapeake Bay. With the decline of the oyster fishery in recent years, displaced watermen have moved to clam harvesting as an alternate source of

*Corresponding author. E-mail: rmann@ vims.edu income. The result has been increasing concern for the extant hard clam stocks and a gradual decline in catch. Hard clam habitat in the Bay is continually threatened and disturbed by activity associated with shoreline and industrial development (e.g., dredging for shipping and dock access). Despite a number of small scale surveys of clam stocks in the Bay there has been only one recent effort focused on stock assessment for management purposes (Wesson 1995) and no comprehensive study of the entire Chesapeake Bay hard clam stocks since Haven et al. (1973). The lack of such data compromises management efforts for ecological services and fishery stability. In this study, we examined the density and distribution of extant Chesapeake Bay hard clam stocks using well proven techniques that have been used in previous oyster stock assessment efforts (Mann \& Evans 1998, Mann \& Evans 2004, Mann et al. 2004) with the objectives of better defining the spatial habitat characteristics of the extant population with respect to substrate and depth and estimating population size.

\section{METHODS}

Field surveys were conducted during 2001 and 2002 within seven regions in Virginia (Fig. 1), namely the James River (2001 and 2002), Elizabeth and Lafayette Rivers (2001), York River (2002), Mobjack Bay (2002), Back River (2002), Poquoson River (2002), and the region northeast of Willoughby Spit known as Ocean View (2002). Regions were established as distinct spatial units that historically supported hard clam populations (Haven et al. 1973, Roegner \& Mann 1991), which may have limited or no connectivity with each other through larval dispersal. Prior to the initiation of field surveys, sampling strata were established within regions on the basis of bathymetry, sediment and salinity data as summarized by Roegner and Mann (1991) to ensure complete sampling coverage. Individual stations within each stratum or area were randomly selected prior to the initiation of the field program. Sampling rate within an area was established at one station per 10-20 acres per Bros and Cowell (1987). All stations sampled were at depths between 1 and $23 \mathrm{~m}$ due to vessel constraints (i.e., draft, cable length). At each station, the bottom was sampled using a hydraulic patent tong with coverage of one square meter. Water depth ( $\mathrm{m}$, from the vessel sounding) and substrate type (catego- 


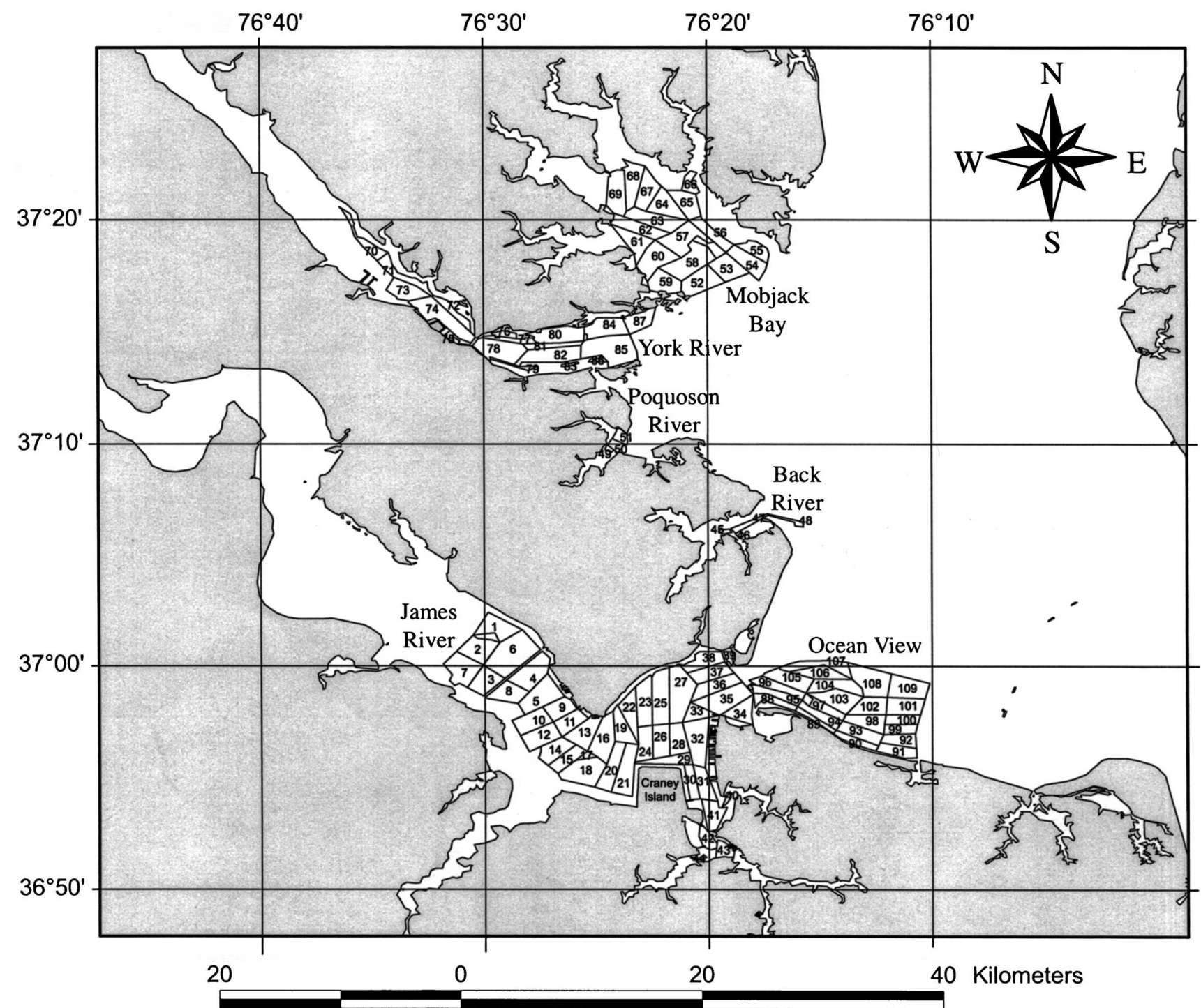

Figure 1. Map of regions within the Virginia portion of the Chesapeake Bay showing sampling strata where hard clam stocks were surveyed during 2001 and 2002.

rized as anoxic mud, mud, sand, or shell on the basis of direct observation prior to culling) were recorded for each station or patent tong grab. The entire patent tong contents at each station were retrieved and returned to the vessel's culling board (often $>50 \mathrm{~kg}$ of material including substrate) for enumeration of live hard clams.

Patent tong grabs were not grouped for analyses by geographic region to avoid artificial distinctions in that we are seeking a description of occupied habitats within potential clam habitat as delineated by historic surveys (Haven et al. 1973) and known environmental tolerances (summarized in Grizzle et al. 2001). Each patent tong grab $(n=7,358)$ had a result (clam density), two habitat descriptors (substrate type, depth), and a stratum number (1-109) associated with it. A discrete numerical variable was assigned to categorize substrate type (anoxic mud -1 , mud -2 , sand -3 , or shell -4$)$ and depth (1-23 in $1 \mathrm{~m}$ bins). Hard clam densities (number of clams collected per $\mathrm{m}^{2}$ ) did not meet the assumptions of normality or homogeneity of variance regardless of the transformation (logarithm, natural logarithm, reciprocal, square root). The data set was unbalanced with regard to substrate type and depth due to natural variability within each strata. The absence of clams (clam density $=0$ ) in $78 \%$ of the total number of patent tong grabs collected (Table 1) further unbalanced the data set. Kruskal Wallis tests were used to evaluate the effects of habitat variables (substrate and depth) and strata number on clam density. Significance levels for all statistics were established at $P=0.05$ a priori. Tukey's test was used for nonparametric posthoc multiple comparisons.

A detrended correspondence analysis (DCA) was used to describe clam density patterns in relation to depth and substrate. The DCA (CANOCO for Windows version 4.0 1998) was detrended with second order polynomials per ter Braak (1995) to avoid potential loss of gradient information during the detrending procedure (Minchin 1987).

\section{RESULTS}

The 2001 to 2002 hard clam survey collected 7,358 patent tong samples containing a total of 4,188 hard clams. Clam densities for individual patent tong grabs ranged from 0-20 live hard clams per 
TABLE 1.

Summary of hard clam densities observed with fishery independent patent tong surveys of Virginia waters during 2001 and 2002 . Regions and strata are shown in Figure 1. Densities reported are average number of hard clams observed per square meter with standard error of the mean (SEM).

\begin{tabular}{|c|c|c|c|c|c|c|c|}
\hline Region & $\begin{array}{l}\text { No. of } \\
\text { Strata }\end{array}$ & $\begin{array}{c}\text { Acreage } \\
\text { (sq m) }\end{array}$ & $\begin{array}{c}\text { No. of Patent } \\
\text { Tong Grabs }\end{array}$ & $\begin{array}{l}\text { No. of Clams } \\
\text { Collected }\end{array}$ & $\begin{array}{c}\text { Average (SEM) } \\
\text { Hard Clam } \\
\text { Density }\end{array}$ & $\begin{array}{l}\text { Average (SEM) } \\
\text { Depth (m) }\end{array}$ & $\begin{array}{l}\text { Estimated Number } \\
\text { of Clams per Region }\end{array}$ \\
\hline Back River & 4 & 406 & 35 & 21 & $0.60(0.23)$ & $2.91(0.19)$ & 874,420 \\
\hline \multicolumn{8}{|l|}{ Elizabeth/Lafayette } \\
\hline Rivers & 5 & 1517 & 115 & 62 & $0.54(0.12)$ & $8.59(0.48)$ & $2,878,817$ \\
\hline Jamer River & 39 & 33404 & 3174 & 3189 & $1.00(0.03)$ & $6.60(0.08)$ & $131,968,971$ \\
\hline Mobjack Bay & 18 & 15658 & 1516 & 209 & $0.14(0.01)$ & $5.06(0.04)$ & $8,974,045$ \\
\hline Ocean View & 22 & 14471 & 1443 & 370 & $0.26(0.02)$ & $6.69(0.04)$ & $15,074,683$ \\
\hline Poquoson River & 3 & 429 & 31 & 11 & $0.35(0.17)$ & $3.41(0.20)$ & 593,699 \\
\hline York River & 18 & 11605 & 1044 & 326 & $0.31(0.03)$ & $7.99(0.16)$ & $23,032,180$ \\
\hline Total & 109 & 77489 & 7358 & 4188 & $0.56(0.09)$ & & $183,396,816$ \\
\hline
\end{tabular}

$\mathrm{m}^{2}$ (Fig. 2). Spatial aggregation was evident in all regions surveyed.

Clam densities decreased significantly across the four types of substrate with the highest densities observed in shell substrate followed by sand, mud and anoxic muds in order of decreasing occupation (Kruskal Wallis, $\mathrm{H}=1,414.27$, $\mathrm{DF}=3, P<0.01$; Fig. $3)$. Less than $1 \%$ of all clams collected were from anoxic mud substrates whereas shell, sand, and mud substrates contained $11 \%$,

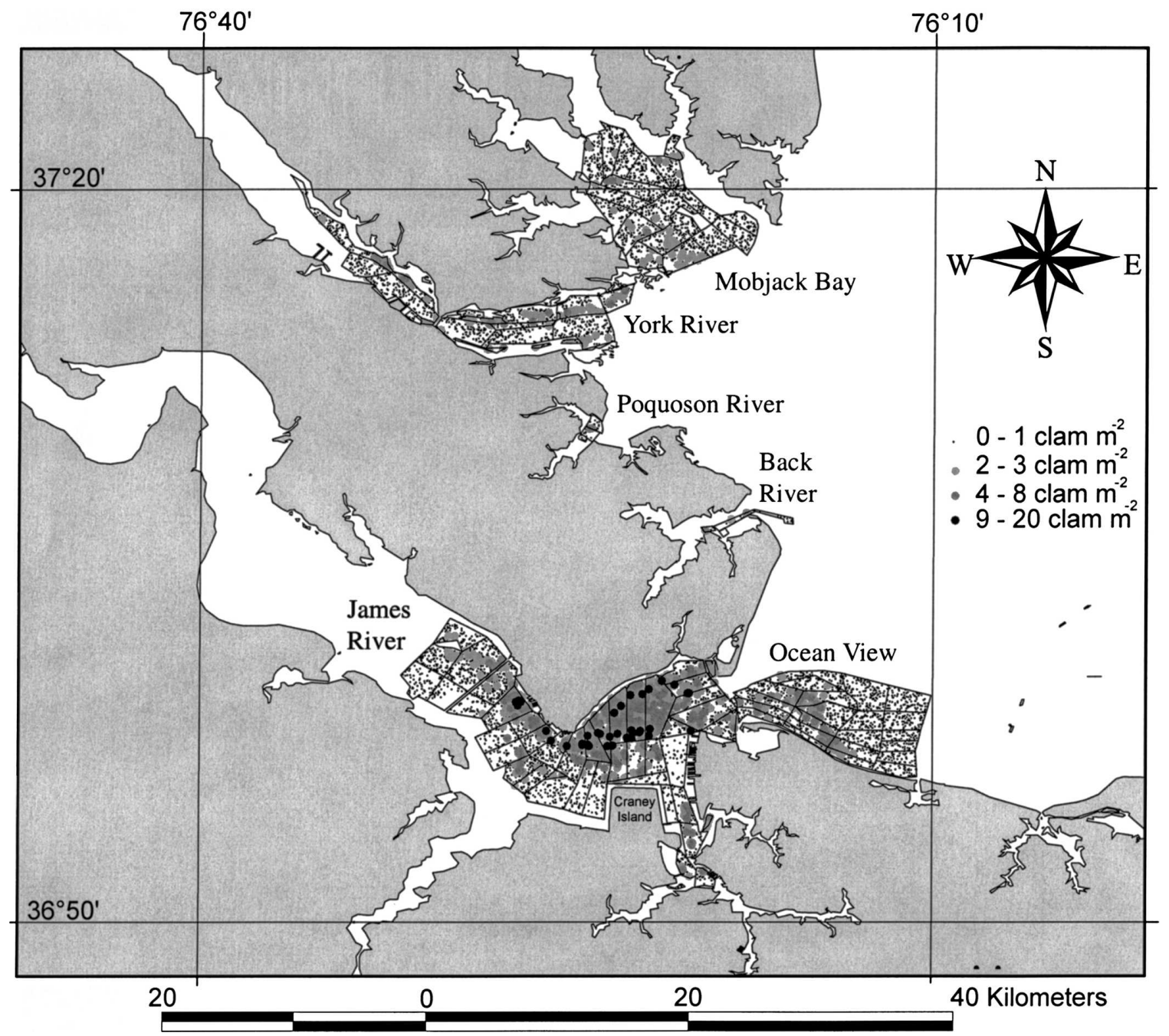

Figure 2. Hard clam density (number $\left.\mathrm{m}^{-2}\right)$ by patent tong grab $(n=7,358$ grabs/samples) in relation to sampling strata. 


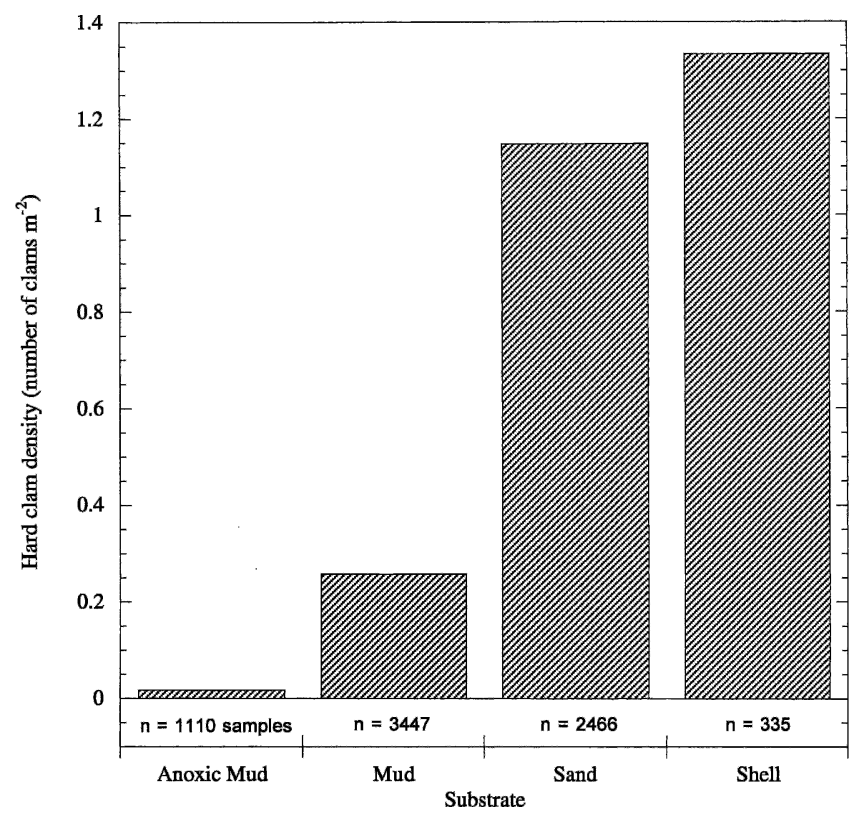

Figure 3. Hard clam density in relation to the four substrate types observed in lower Chesapeake Bay: anoxic mud, mud, sand and shell. The total number of patent tong grabs/samples was 7,358 .

$68 \%$ and $21 \%$ of clams, respectively. Although shell and sand substrates contained the highest observed densities of hard clams, these substrate types were only present in $38 \%$ of patent tong samples collected from potential clam habitats (Fig. 4).

Hard clams were significantly more abundant at 4,10 and $20 \mathrm{~m}$ than at any other depth (Kruskal Wallis, $\mathrm{H}=288.87, \mathrm{DF}=19$, $P<0.001$; Fig. 5). Clam collections at these three depths (20\% of all patent tong grabs) provided $32 \%$ of the total number of clams observed. Water depths in excess of $11 \mathrm{~m}$ were observed only in the York River, James River and Ocean View regions with average depths in these regions of 8.0, 6.6 and $6.7 \mathrm{~m}$, respectively (Table 1). Average depths in the other regions ranged from $2.9 \mathrm{~m}$ (Back River) to $8.6 \mathrm{~m}$ (Elizabeth/Lafayette River, Table 1).

The detrended correspondence analysis (DCA) of clam densities in relation to substrate type and depth grouped samples at depths $<11 \mathrm{~m}$ on one end of Axis I with shell substrate and those from depths $>11 \mathrm{~m}$ on the opposite end of Axis I with sand and mud substrates (Fig. 6). Axis I describes a gradient in sediment particle size moving from right to left. Axis II describes a gradient in the influx of deeper, more saline water due to incoming tidal flows associated with channels typically found in deeper portions of these regions or subestuaries. The variance, as indicated by the eigenvalues, explained by these axes was 0.48 (Axis I) and 0.09 (Axis II).

Sampling strata were used as a factor in analyzing clam density patterns to provide a local (100s of m) scale geographic framework within which observed average clam densities (total number of clams observed/total number of $\mathrm{m}^{-2}$ patent tong grabs collected for each strata) could be evaluated. Observed clam densities were significantly different across strata (Kruskal-Wallis, $\mathrm{H}=$ $2,252.18, \mathrm{DF}=107, P<0.001)$. A posthoc multiple comparison test delineated four groups of strata corresponding to zero, low (0.01-0.8 clams $\left.\mathrm{m}^{-2}\right)$, medium (0.9-1.4 clams $\left.^{-2}\right)$, high (1.5-2.1 clams $\left.\mathrm{m}^{-2}\right)$ and very high $\left(>2.2\right.$ clams $\left.\mathrm{m}^{-2}\right)$ average densities (Fig. 7).
Average clam density per stratum throughout Mobjack Bay was low ranging from 0.01 (stratum 53, Fig. 1 and 5) to $0.51 \mathrm{~m}^{-2}$ (stratum 52, Fig. 1, 2 and 7) with clams completely absent from strata 54 and 64 . The highest concentrations of clams were found in the southwest corner of Mobjack Bay (strata 52, 58, 59 and 60, Fig. 1, 2 and 7) and at the mouth of the East River (stratum 66, Fig. 1, 2 and 7). Although clams were observed in every York River

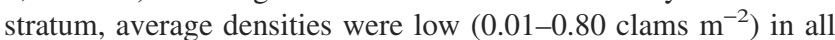
strata except 77 and 79 (Fig. 1, 2 and 7). These two strata with medium (0.90-1.4 clams $\mathrm{m}^{-2}$ ) average clam densities are immediately downstream of Gloucester Point on either side of the deep (>20 m) navigation channel (Fig. 1, 2 and 7). All strata sampled in the Back and Poquoson Rivers had clams present at low (0.01-0.8 clams $\mathrm{m}^{-2}$ ) average densities (Fig. 1, 2, and 7).

The Ocean View region (Fig. 1) is bounded in the west by the Interstate 64 bridge-tunnel crossing of the mouth of the James River, on the northern edge by the major shipping navigation channel between the Chesapeake Bay mouth and the James River, and in the east by a line progressing approximately due north and then more northeasterly from the mouth of Little Creek to the navigation channel. This region has primarily sand substrate that progresses with increasing depth from the shoreline to the navigation channel. Clams were absent from the 8 northeastern strata (strata 92, 98, 99, 100, 101, 102, 108, 109, Fig. 1, 2 and 7). Of the remaining 14 strata, low $(0.01-0.8)$ average densities were observed in 12 and medium (0.9-1.4) average densities were observed in strata 94 and 97 which are adjacent to each other along the 6-7 m contour.

The Elizabeth and Lafayette Rivers are small tributaries that feed into the lower James River near Craney Island (Fig. 1). Average clam density at the mouth of the Lafayette River was high

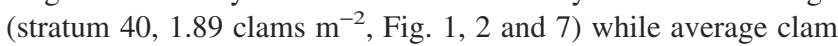
densities were low throughout the Elizabeth River (strata 41-44, Fig. 1, 2 and 7).

In general, hard clams were more abundant in the James River than in any other region sampled. The highest average densities per stratum of hard clams observed in this survey (very high: 2.1-3.1 clams $\mathrm{m}^{-2}$ ) were observed in the lower James River north of the navigation channel between Newport News Small Boat Harbor and the mouth of the Hampton River (strata 19, 22, 23, 25, and 27, Fig. 1, 2 and 7). Within this group, average clam densities ranged from 2.23 (stratum 27) to 3.03 (stratum 25) clams $\mathrm{m}^{-2}$. High (1.5-2.1) average clam densities were observed in strata 5 and 24 (Fig. 1 and 5) and medium (0.9-1.4) average densities were observed inshore and upstream of Newport News Point (strata 9 and 11, Fig. 1 and 5), directly off Newport News point in a region of tidal front convergence (strata 16 and 17, Fig. 1 and 5), near Middle Ground light (strata 26) and at the mouth of the Hampton River (strata 37 and 38, Fig. 1 and 5). Within the rest of the James River, clams were absent from strata 3, 7 and 18 (Fig. 1 and 5) along the southern shoreline below the navigation channel.

Fishery independent estimates of hard clam standing stock in the seven regions sampled range from $5.93 \times 10^{5}$ in the Poquoson River (Table 1, Fig. 1) to $1.31 \times 10^{8}$ in the James River (Table 1, Fig. 1). The total estimated standing stock in these regions as of 2001 to 2002 is $1.83 \times 10^{8}$ hard clams (Table 1 ).

\section{DISCUSSION}

Hard clam distribution in lower Chesapeake Bay habitats is not uniform and modern hard clam populations do not seem to occupy 


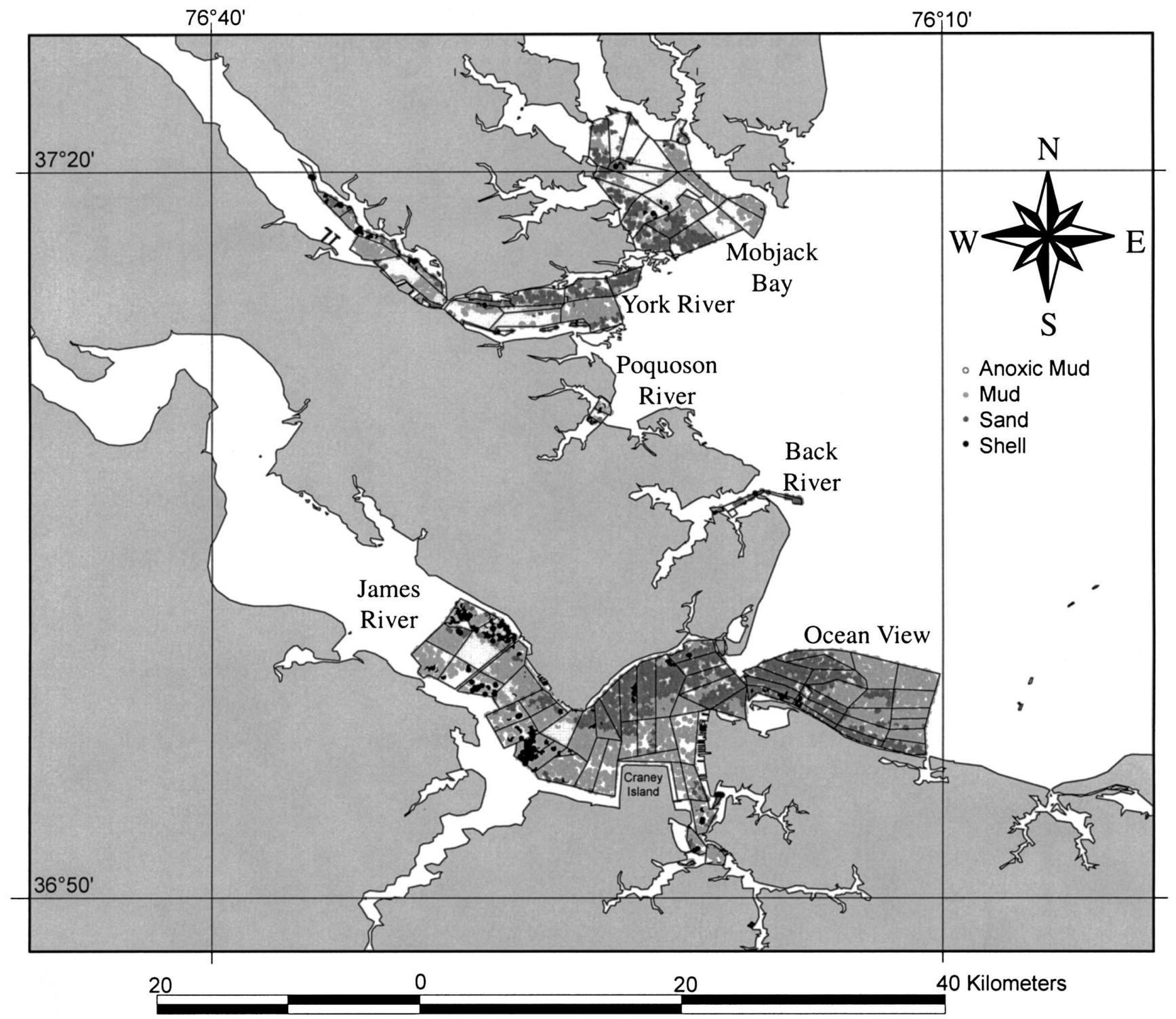

Figure 4. Distribution of observed substrate types within sampling strata by patent tong grab.

all of the habitat historically delineated as potential habitat (Haven et al. 1973, Roegner \& Mann 1991). Clams were present in only $22 \%$ of the potential clam habitat surveyed. Hard clam density in Chesapeake Bay is positively associated with increasing sediment grain size; $78 \%$ of all clams collected were found in shell or sand habitats; however, $44 \%$ of sand habitats and $54 \%$ of shell habitats were unoccupied suggesting that even habitat types that typically support higher clam densities (Wells 1957, Carriker 1959, Saila et al. 1967, Fegley 2001, Kraeuter 2001) may currently be underused. Thus caution is advised when considering extrapolating observed densities within a sediment type across the range of available habitat with that sediment type. Habitat use patterns for hard clams may be related to changes in habitat quality across spatial scales within and between river basins related to watershed development and management and temporal scales potentially equivalent to the animal's life span on the order of decades.

Average clam densities observed during 2001 to 2002 fall into 5 ranges: zero, low (0.01-0.80 clams $\mathrm{m}^{-2}$ ), medium (0.9-1.4), high (1.5-2.1) and very high (2.1-3.1) with the highest densities ob- served in the lower James River. Prior to this survey, the most recent complete survey of Virginia's hard clam resources was done by Haven et al. (1973). Haven et al. (1973) categorized clam

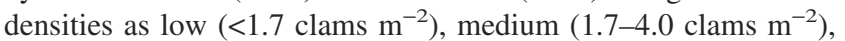
and high $\left(>4.1\right.$ clams $\mathrm{m}^{-2}$ ). They observed high clam densities in areas corresponding to portions of the modern James River strata $19,22,23,25$ and 27. Whereas the geographic foci of hard clam abundance does not appear to have changed between 1969 to 1972 and 2001 and 2002, the differences in the range of available clam densities are striking. The maximum observed clam density in 2001 to 2002 surveys was 3.03 clams as compared with densities in excess of 4.1 clams m$^{-2}$ observed in 1969 to 1972 (Haven et al. 1973).

The paucity of clams observed during 2001 to 2002 in regions in the lower James River and Ocean View where they previously occurred is troubling in light of the 1998 discovery of an introduced shellfish predator, the veined rapa whelk (Rapana venosa) in lower Chesapeake Bay (Harding \& Mann 1999). This large gastropod is responsible for the depletion of bivalve stocks in the 


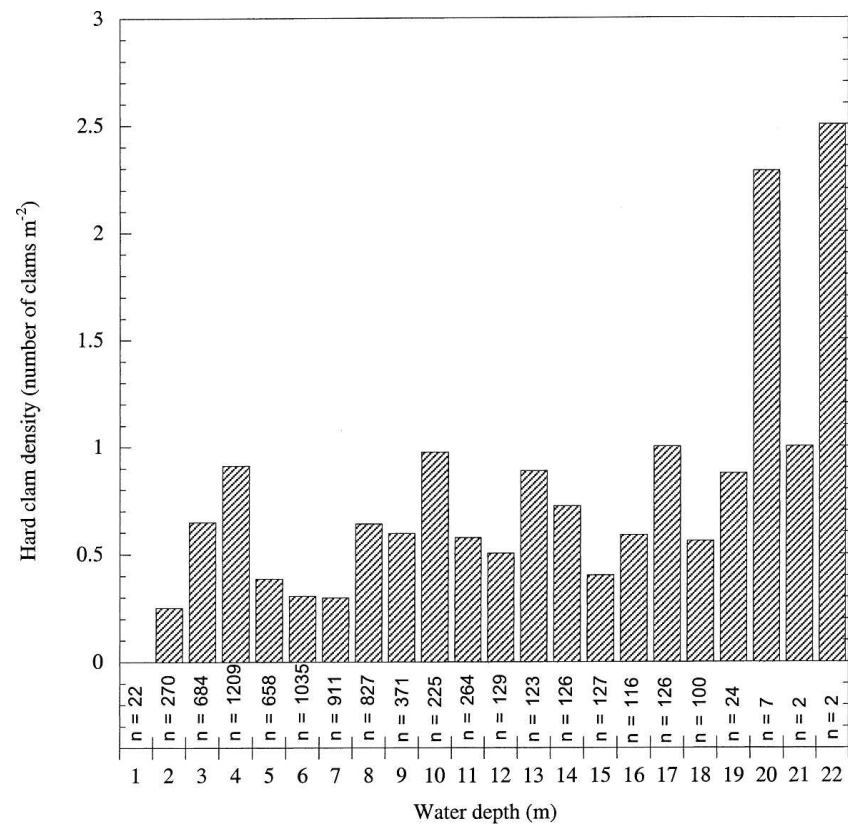

Figure 5. Hard clam density in relation to water depth category (1-m bin). $n$ values given are for the number of patent tong grabs/samples within a depth category.

Black Sea (Chukhchin 1984, Zolotarev 1996). The known distribution of rapa whelks in the Chesapeake Bay completely overlaps the distribution of hard clams (Roegner \& Mann 1991, Harding \& Mann 1999, Harding \& Mann 2005). Adults of both species tolerate salinities on the order of 12 ppt (Roegner \& Mann 1991, Harding \& Mann 1999, Mann \& Harding 2003) and readily burrow into sand substrate habitats (Roegner \& Mann 1991, Harding \& Mann 1999). Of the 9,548 rapa whelks collected by the VIMS rapa whelk bounty program as of July 1, 2004, a total of 83\% of these rapa whelks had been collected from the James River (47\%) and Ocean View (36\%) regions (Harding \& Mann, unpublished data).

Unlike oysters (Crassostrea virginica) where reef structure provides protection or refuge from predation for recently settled animals, recruitment processes in hard clams are poorly understood. Hard clams from 1-30 mm are vulnerable to a wide suite of predators (see Kraeuter 2001) and postsettlement mortality plays a major role in recruitment success. To maintain population densities, hard clams must have substantial recruitment events. Low density predation refuges have been observed for bivalve prey of blue crabs (Callinectes sapidus) at densities on the order of 5 bivalves $\mathrm{m}^{-2}$ (Lipcius \& Hines 1986, Eggleston et al. 1992). Substrate particle size also influences predator success and both Lipcius and Hines (1986) and Eggleston et al. (1992) observed higher rates of predation by crabs on bivalves in mud than sand. Heterogeneous substrates (sand, shell) and root or rhizome mats have demonstrated efficacy as predation refuges for hard clams (e.g.,Wells 1957, Peterson 1986, Fegley 2001, Kraeuter 2001).

Observed hard clam densities in Chesapeake Bay fall below the suggested threshold for low density predation refuge and within the sand and shell substrates that offer size related predation refuges. Essential or protected habitat for hard clams should be carefully delineated based on occupied high quality habitat. Habitat use by this species defines their populations as relatively restricted spatially. Populations with high numbers represent functional re-

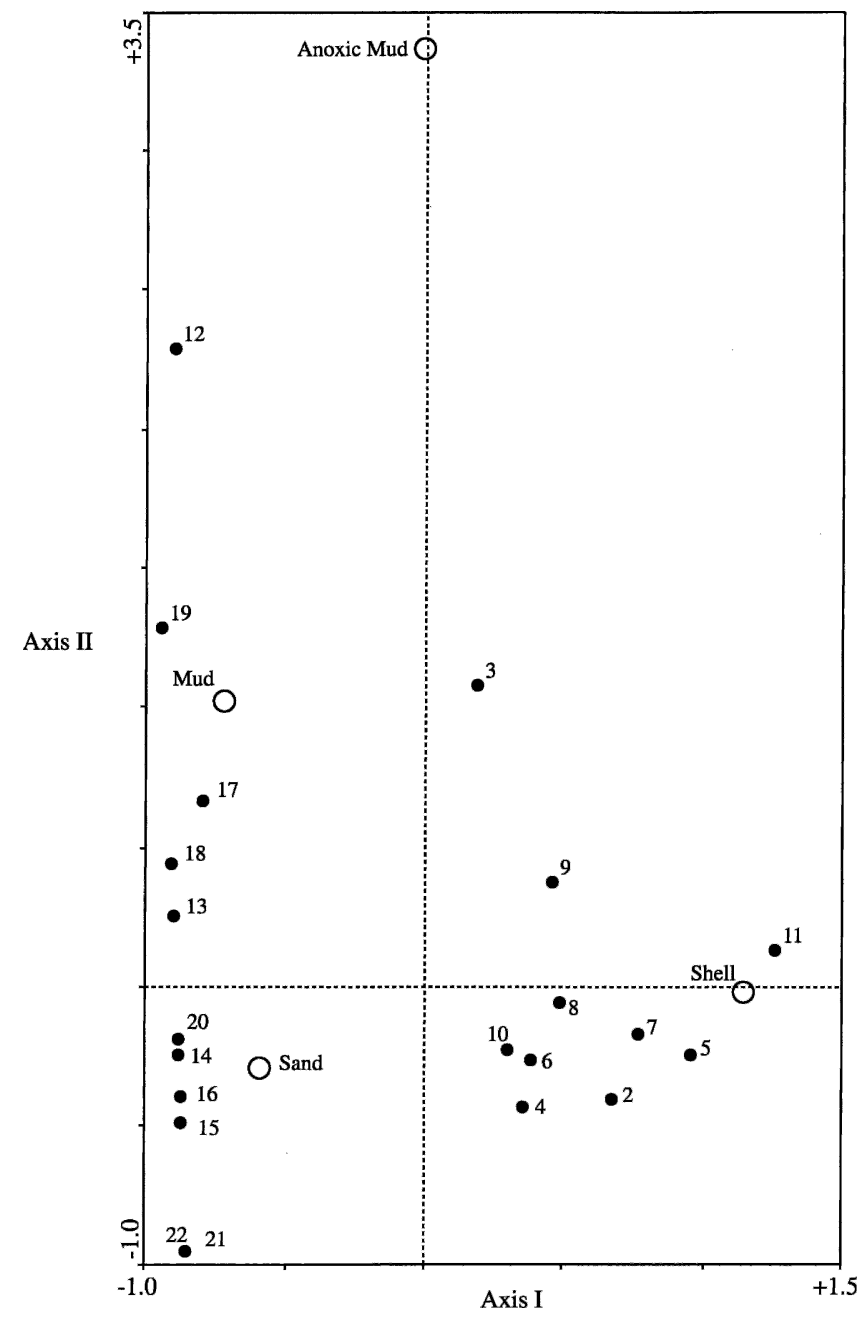

Figure 6. Ordination diagram from DCA analysis of clam density in relation to depth (m) and substrate type. Depth categories (1-m bin) are shown with closed circles whereas open circles represent substrate types.

productive units because of density dependent fertilization processes (Levitan 1991). Low densities represent the end products of larval exports and recruitment but are probably reproductive sinks rather than sources. Further research is needed to establish the boundary between reproductive extinction and low, but viable, population densities. Unfortunately, higher clam densities will be the preferred target of commercial fishing activity and a balance must be struck in fishery management to limit effort in areas with highly susceptible populations. To their credit the fishery regulatory agency has been working in concert with commercial fishermen for over a decade to develop brood stock sanctuaries to service the hard clam populations. The long term contributions of these sanctuaries remain to be examined.

\section{ACKNOWLEDGMENTS}

This study reflects the cumulative efforts of many individuals. Allen Godshall, Vernon Rowe and John Ericson of VMRC worked tirelessly on field surveys. Roy Insley, Chad Boyce, and Ms. Stephanie Iverson of the Statistics Division at VMRC provided unique insight into the nature of the clam fishery. Dr. David Evans (VIMS) provided valuable statistical advice. Grant support of the 


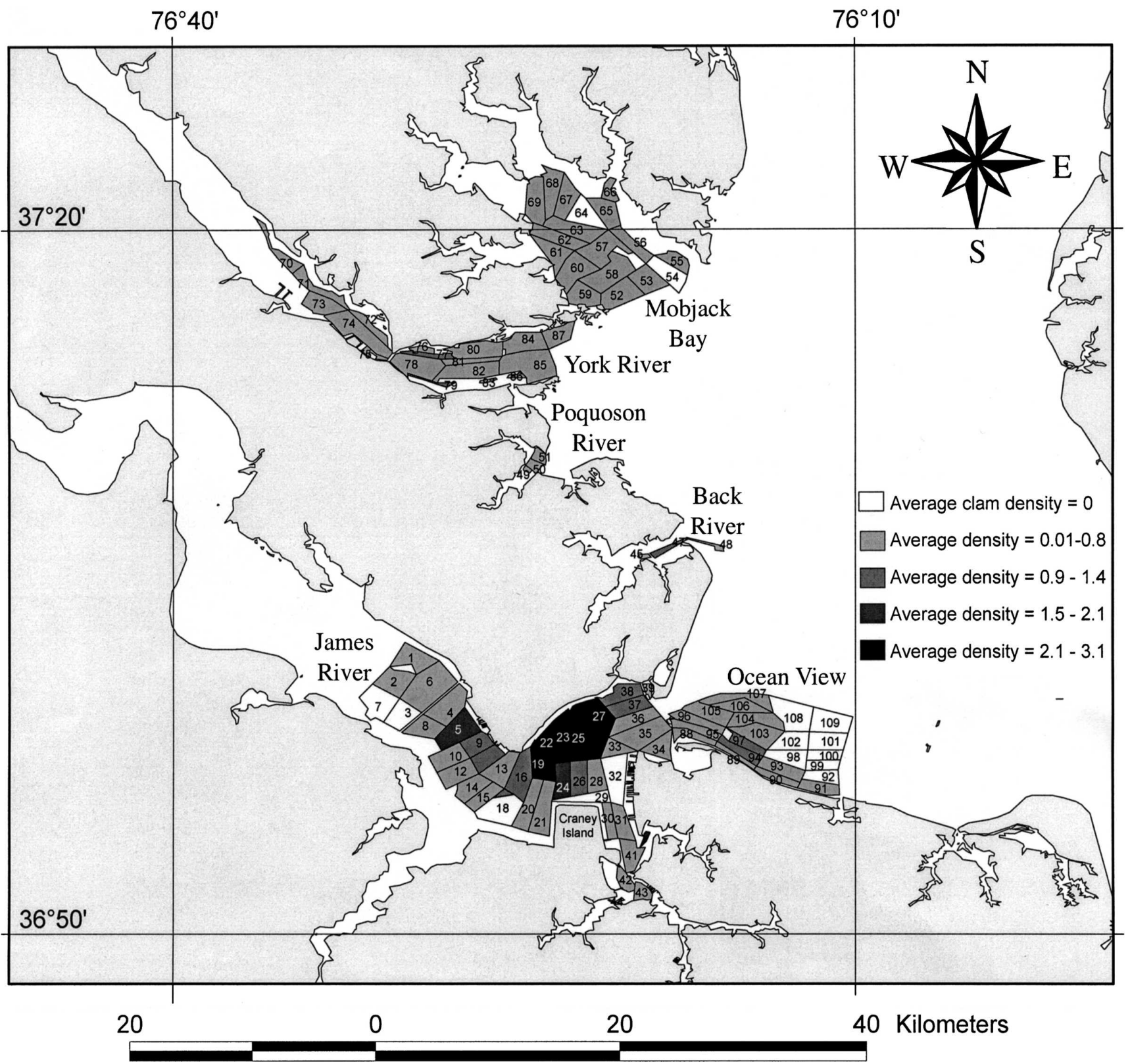

Figure 7. Hard clam habitat in Chesapeake Bay as indicated by zones of zero, low (0.01-0.8 clams $\left.\mathbf{m}^{-2}\right)$, medium (0.9-1.4), high (1.5-2.1), and very high (2.1-3.1) clam densities recorded in strata by fishery independent surveys during 2001-02. Categories of clam density were significantly different from each other (Kruskal Wallis, $\mathrm{H}=\mathbf{2 , 2 5 2 . 1 8}$, DF $=107, P<0.001$ ).

NOAA Chesapeake Bay Stock Assessment Committee under contract number NA07FU0535 is gratefully acknowledged. This is
Contribution Number 2674 from the Virginia Institute of Marine Science, Gloucester Point, Virginia.

\section{LITERATURE CITED}

Bros, W. E. \& B. C. Cowell. 1987. A technique for optimizing sample size (replication). J. Exp. Mar. Biol. Ecol. 114:63-71.

Carriker, M. 1959. The role of physical and biological factors in the culture of Crassostrea and Mercenaria in a saltwater pond. Ecological Monographs. 29(3):219-266.

Chukhchin, V. 1984. Ecology of gastropoda from the Black Sea (in Russian). Naukova Dumka. Kiev. 176 pp.

Eggleston, D., R. Lipcius \& A. Hines. 1992. Density-dependent predation by blue crabs upon infaunal clam species with contrasting distribution and abundance patterns. Mar. Ecol. Prog. Ser. 85:55-68.

Fegley, S. 2001. Demography and dynamics of hard clam populations. In: J. Kraeuter \& M. Castagna, editors. Biology of the hard clam. New York: Elsevier Science. pp. 383-422.

Grizzle, R., V. M. Bricelji \& S. Shumway. 2001. Physiological ecology of Mercenaria mercenaria. In: J. Kraeuter \& M. Castagna, editors. Biology of the hard clam. New York: Elsevier Science. pp. 305-382. 
Harding, J. M. \& R. Mann. 1999. Observations on the biology of the veined rapa whelk Rapana venosa (Valenciennes, 1846) in the Chesapeake Bay. J. Shellfish Res. 18(1):9-18.

Harding, J. M. \& R. Mann. 2005. Veined rapa whelk Rapana venosa range extension in the Virginia waters of Chesapeake bay. J. Shellfish Res. 24(2):

Harte, M. 2001. Systematics and taxonomy. In: J. Kraeuter \& M. Castagna, editors. Biology of the hard clam. New York: Elsevier Science. pp. $1-51$.

Haven, D., J. Loesch \& J. Whitcomb. 1973. An investigation into commercial aspects of the hard clam fishery and development of commercial gear for the harvest of molluscs. Final contract report for the period July 1, 1970 through June 30, 1973. Commercial Fisheries and Research Development Act. Virginia Institute of Marine Science, Gloucester Point, VA. 112 pp.

Kraeuter, J. 2001. Predators and predation. In: J. Kraeuter \& M. Castagna, editors. Biology of the hard clam. New York: Elsevier Science. pp. 441-590.

Levitan, D. 1991. Influence of body size and population density on fertilization success and reproductive output in a free-spawning invertebrate. Biol. Bull. 181:261-268.

Lipcius, R. \& A. Hines. 1986. Variable functional responses of a marine predator in dissimilar homogenous microhabitats. Ecology. 67(5): 1361-1371.

Mann, R. \& D. Evans. 1998. Estimation of oyster, Crassostrea virginica, standing stock, larval production and advective loss in relation to observed recruitment in the James River, Virginia. J. Shellfish Res. 17(1): 239-254.

Mann, R. \& D. Evans. 2004. Site selection for oyster habitat rehabilitation in the Virginia portion of the Chesapeake Bay. J. Shellfish. Res. 23(1): 41-49.

Mann, R. \& J. M. Harding. 2003. Salinity tolerance of larval Rapana venosa: implications for dispersal and establishment of an invading predatory gastropod on the North American Atlantic coast. Biol. Bull. 204:96-103.

Mann, R., M. Southworth, J. M. Harding \& J. A. Wesson. 2004. A comparison of dredge and patent tongs for estimation of oyster populations. J. Shellfish Res. 23:387-390.

Minchin, P. 1987. An evaluation of the relative robustness of techniques for ecological ordination. Vegetatio. 67:1167-1179.

Peterson, C. 1986. Enhancement of Mercenaria mercenaria densities in seagrass beds: is pattern fixed during settlement season or altered by subsequent differential survival? Limnol. Oceanogra. 31(1):200-205.

Peterson, C. 2001. Integrating nutritional physiology and ecology to explain interactions between physics and biology in Mercenaria mercenaria. In: J. Kraeuter \& M. Castagna, eds. Biology of the hard clam. New York: Elsevier Science. pp. 423-440.

Roegner, G. C. \& R. Mann. 1991. The hard shell clam. In: S. Funderburk, J. A. Mihursky. S. J. Jordan \& D. Riley, editors. Habitat requirements for Chesapeake Bay living resources. Annapolis, MD: U.S.F.W.S. 5.15.17 .

Saila, S., J. Flowers \& M. Cannario. 1967. Factors affecting the relative abundance of Mercenaria mercenaria in the Providence River, Rhode Island. Proc. Natl. Shellfish. Assoc. 57:83-89.

Ter Braak, C. 1995. Ordination. In: R. Jongman, C. ter Braak \& O. Van Tongeren, editors. Data analysis in community and landscape ecology. Cambridge, England: Cambridge University Press. pp. 91-173.

Wells, H. W. 1957. Abundance of the hard clam Mercenaria mercenaria in relation to environmental factors. Ecology. 38:123-128.

Wesson, J. A. 1995. Fishery independent stock assessment of Virginia's clam population of the Chesapeake Bay. Final report to Virginia Coastal Resources Management Program, Dept. of Environmental Quality. NOAA Grant \# NA37OZ 036-01. 21 pp.

Zolotarev, V. 1996. The Black Sea ecosystem changes related to the introduction of new mollusc species. Mar. Ecol. 17(1-3):227-236. 